Preprints of the

Max Planck Institute for

Research on Collective Goods

Bonn 2017/3

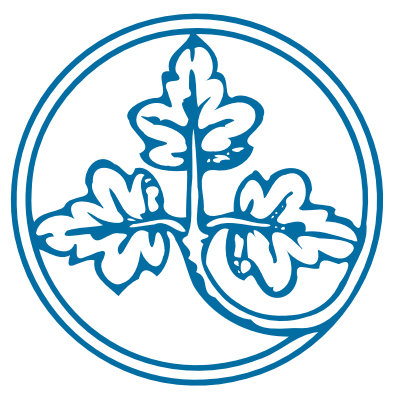

Carving out legacy assets: a successful tool for bank restructuring?

Martin Hellwig

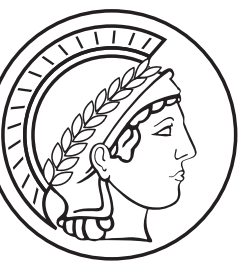




\title{
Carving out legacy assets: a successful tool for bank restructuring?
}

\author{
Martin Hellwig
}

March 2017

This material was originally published in a paper provided at the request of the Committee on Economic and Monetary Affairs of the European Parliament and commissioned by the Directorate General for Internal Policies of the Union and supervised by its Economic Governance Support Unit (EGOV). The opinions expressed in this document are the sole responsibility of the author and do not necessarily represent the official position of the European Parliament. The original paper is available on the European Parliament's webpage http://www.europarl.europa.eu/RegData/ etudes/IDAN/2017/ 587399/IPOL_IDA(2017)587399_EN.pdf .

(C) European Union 2016. Copyright remains with the European Union at all times. 
IPOL $\mid$ DIRECTORATE-GENERAL FOR INTERNAL POLICIES

EGOV ECONOMIC GOVERNANCE SUPPORT UNIT

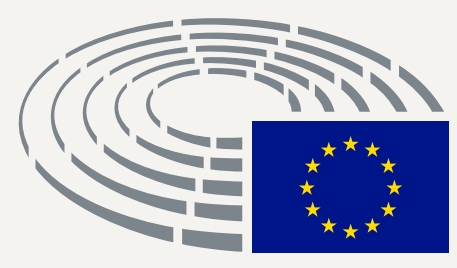

European Parliament

\author{
IN-DEPTH ANALYSIS
}

\title{
Carving out legacy assets:
}

a successful tool for bank restructuring?

External author: Martin Hellwig Max Planck Institute for Research in Collective Goods

Provided at the request of the Economic and Monetary Affairs Committee 


\title{
IN-DEPTH ANALYSIS
}

\section{Carving out legacy assets: a successful tool for bank restructuring?}

\author{
External author: Martin Hellwig \\ Max Planck Institute for Research in Collective Goods
}

\author{
Provided in advance of the public hearing \\ with the Chair of the Single Resolution Board \\ in ECON \\ on 22 March 2017
}

\begin{abstract}
Beginning with the proposal by Enria (2017), the paper discusses the scope for successful bank restructuring through a carveout of impaired assets and a transfer of these assets to a government-sponsored asset management company. The paper argues that the success of such an operation requires a use of public funds, either outright or through contingent commitments. Clawback provisions are problematic because they create contingent liabilities that merely shift risks from the assets side to the liabilities sides of banks' balance sheets. The paper distinguishes between asset impairments coming from considerations of prospective returns and asset impairments coming from frictions in the markets in which these assets are traded. It also distinguishes between threats to bank solvency and threats to bank funding/liquidity. In each case, the success of bank restructuring from asset carveouts depends on the extent to which threats to the bank's solvency is eliminated. If these threats concern bank funding and asset liquidations at depressed prices, public funds may eventually not be needed. If threats to bank solvency come from nonperforming loans, taxpayer support may be essential. The notion of "real economic value" as the price at which assets should be transferred is problematic and leaves ample room for hidden subsidies. The success of restructuring of the individual bank may itself come at a risk to financial stability as the preservation of existing capacities maintains competitive pressure and depresses bank profitability. Additional risks may come from the burden on the government's fiscal stance.
\end{abstract}


This paper was requested by the European Parliament's Economic and Monetary Affairs Committee.

\section{AUTHOR}

Martin Hellwig, Max Planck Institute for Research on Collective Goods

\section{RESPONSIBLE ADMINISTRATOR}

Benoit Mesnard

Economic Governance Support Unit

Directorate for Economic and Scientific Policies

Directorate-General for the Internal Policies of the Union

European Parliament

B-1047 Brussels

\section{LANGUAGE VERSION}

Original: EN

\section{ABOUT THE EDITOR}

Economic Governance Support Unit provides in-house and external expertise to support EP committees and other parliamentary bodies in playing an effective role within the European Union framework for coordination and surveillance of economic and fiscal policies.

E-mail: egov@ep.europa.eu

This document is also available on Economic and Monetary Affairs Committee homepage at: http://www.europarl.europa.eu/committees/en/ECON/home.html

Manuscript completed in March 2017

(C) European Union, 2017

\section{DISCLAIMER}

The opinions expressed in this document are the sole responsibility of the author and do not necessarily represent the official position of the European Parliament.

Reproduction and translation for non-commercial purposes are authorised, provided the source is acknowledged and the publisher is given prior notice and sent a copy. 


\section{CONTENTS}

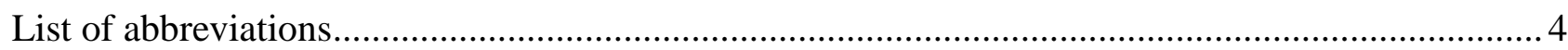

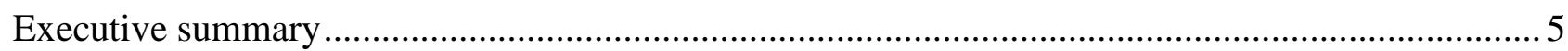

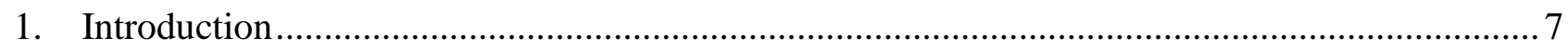

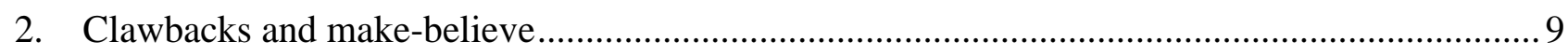

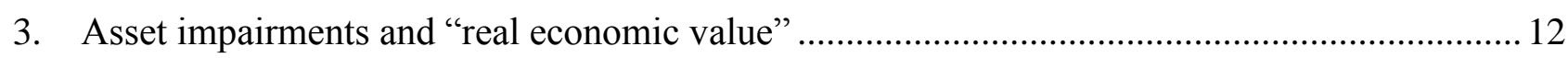

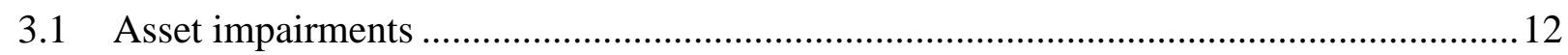

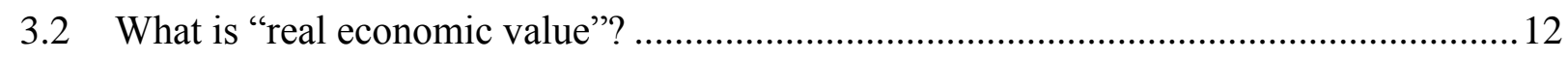

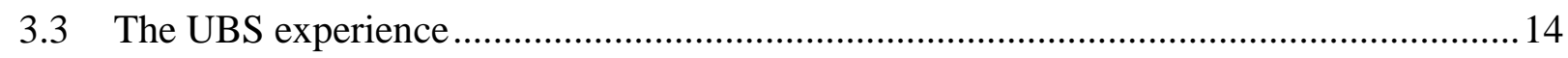

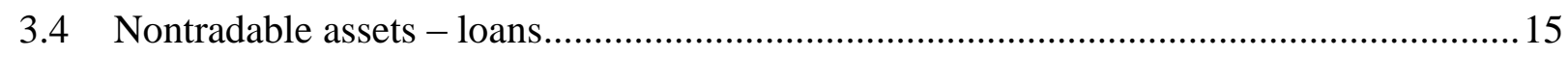

4. Asset carveouts, bank restructuring, and financial stability ............................................ 18

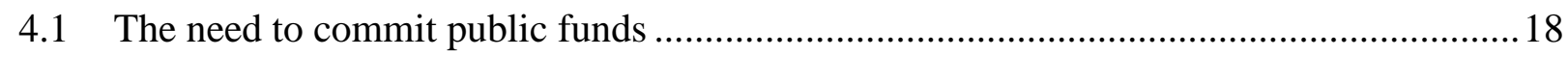

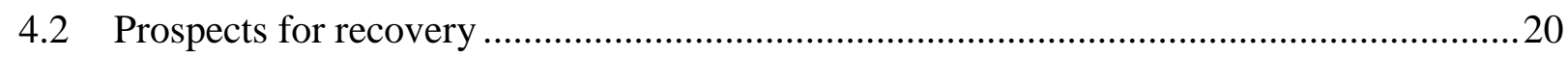

4.3 The conflict between the preservation of banks and bank profitability .........................22

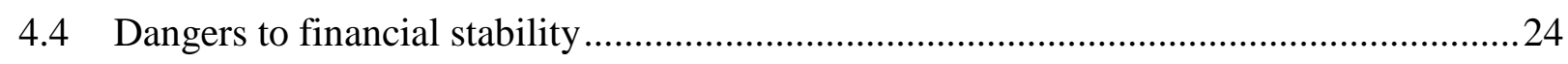

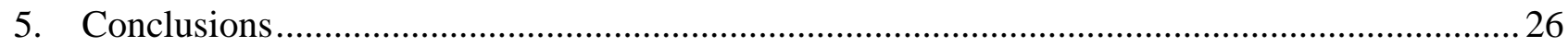

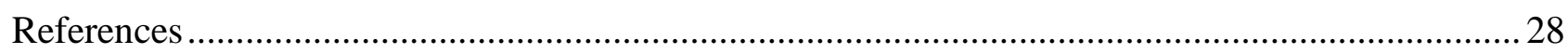




\section{LIST OF ABBREVIATIONS}

BRRD Bank Recovery and Resolution Directive

EAA Erste AbwicklungsAnstalt

EBA European Banking Authority

ECB European Central Bank

FDIC Federal Deposit Insurance Corporation

FMSA Finanzmarktstabilisierungsanstalt

GDP Gross Domestic Product

MREL Minimum Required Eligible Liabilities

NAMA National Asset Management Agency

SRM Single Resolution Mechanism

TLAC Total Loss Absorbing Capacity 


\section{EXECUTIVE SUMMARY}

The large stock of nonperforming loans in European banks is a cause of bank weakness, which distorts decisions on bank lending and harms economic growth. If the banks themselves were sufficiently strong, they would address the problem on their own behalf, initiating insolvency proceedings or restructuring loans, and taking the necessary writedowns without too much of an illusion as to what they will be able to recover if they just leave things as they are, possibly financing loan rollovers so as to avoid credit events. If banks themselves are weak, their strategies may be distorted by the desire to avoid writedowns that might put their own solvency into question. For the overall economy, these distortions are expensive because they harm new lending and economic growth.

The paper discusses proposals to deal with the problem by having banks transfer nonperforming loans and other impaired assets to a national or an EU-wide asset management company that would then try to wind the stock of impaired assets down, possibly by selling packages to third parties, possibly by just managing the loans or the loan collaterals. The main proposition is that, while such proposals may indeed solve the problem, they will only do so if they involve a commitment of taxpayer money. In relation to a recovery and resolution procedure, such proposals effectively shift some of the burden of impaired assets from bail-in-able creditors to public budgets.

This proposition contradicts the suggestion by Enria (2017) that there is no risk to taxpayers if the arrangement involves clawback provisions by which losses of the asset management company must eventually be borne by the banks themselves. Even on its own terms, the suggestion is invalid if clawback provisions are junior to outstanding debt and the equity of the banks is insufficient to cover the losses in question. Moreover, if such clawback provisions are credible, they are likely to defeat the purpose of the exercise because the banks' shareholders - and management remunerated according to its contribution to shareholder value - are not really freed from the risks of the assets in question. These risks are merely shifted from the assets side to the liabilities side of the banks' balance sheets, as the clawback provisions create contingent liabilities that are senior to the shareholders' claims.

The effectiveness of a carveout and transfer of assets to an asset management company will depend on the extent to which threats to the banks' solvency are averted. If such threats come from a prospect of inefficient asset liquidations at low prices in panicky markets, the operation may end up being successful without taxpayers taking a hit (although they are at risk in the interim). An example is provided by the experience of UBS and the Swiss National Bank's StabFund from 2008 to 2013. In contrast, if threats to bank solvency come from the underlying returns on the assets, e.g. delays and defaults in debt service on loans, prospects of recovery may be slim, and the restoration of bank solvency outside of resolution is likely to require taxpayer money.

Most loans are by their very nature not tradable without substantial discounts, even in normal times. The benefits of moving the administration of such loans away from the originating bank would therefore not come from an improvement in their tradability but from additional leeway for disposing of these assets without incentive distortions delaying the recognition of unavoidable losses or funding imposing a liquidation of assets at a loss. Time horizons for the winding down of such loan portfolios can be very long.

Addressing the problems through an asset management company rather than a recovery and resolution procedure maintains the originating bank in existence without much disruption. Such continuity in the organization has advantages for the smooth management of the bank's operations, but also has costs because (i) the transfer of assets must be based on contracts, with the consent of the bank, rather than administrative fiat and (ii) taking the continued existence of the originating bank for granted may imply that excess capacities in markets are not reduced, leaving competitive pressures high and depressing the profitability of (other) banks. 
Determination of the transfer price, "real economy value", is a key problem. With nontraded assets such as loans, there is an element of arbitrariness in valuation, which requires an assessment of probabilities of recovery of loan customers when there are hardly any data on which such an assessment could be based. The determination of transfer prices therefore provides some scope for hidden recapitalizations even if the authorities try to prevent that. Such hidden recapitalizations may well contribute to the recovery of the bank in question but they raise serious issues of governance, competition policy and financial stability. 


\section{INTRODUCTION}

In dealing with problem banks in the crisis of 2007-2009, European countries and the United States have chosen very different modes of intervention. In the United States, the government took direct control of those banks that were in trouble and that were not acquired by other banks, mostly through the Federal Deposit Insurance Corporation (FDIC), which then proceeded to dispose of the banks' operations and assets as best it could. ${ }^{1}$ In Europe, most governments refrained from taking control and instead provided support in the form of guarantees and the transfer of "toxic assets" to asset management companies, so-called "bad banks".

To some extent, the difference in approaches taken reflects differences in institutional and legal traditions. The United States had a long tradition of resolving problem banks by having the deposit insurer take control and dispose of their assets. European countries did not have such a tradition but, in cases where private-sector solutions could not be found, they dealt with problem banks under general insolvency law or under regulatory rules that followed the logic of insolvency law, with priority given to creditor protection and the preservation of assets, regardless of the systemic effects of, e.g., an asset freeze. Given the fears of a system meltdown that had been raised by the Lehman bankruptcy in 2008, authorities in European countries did not want to rely on these rules and instead provided support without taking control, relying on the participating banks' consent rather than government fiat. $^{2}$

Since then, the legal rules in Europe have been changed and institutions have been set up to deal with problem banks through statutory government intervention outside of insolvency law and with a view to protecting the financial system (and taxpayers) and not only the creditors of banks. The Bank Recovery and Resolution Directive (BRRD) provides for a common set of rules for this purpose; for large banks in the euro area, the Single Resolution Mechanism (SRM) provides an institutional framework. The BRRD explicitly provides for the bailing in of even senior unsecured creditors.

However, despite the fact that substantial problems in banking systems persist, the new rules and institutions for dealing with problem banks have not yet been called upon. Instead, new "bad banks" have been created, such as Atlante in Italy and hsh portfoliomanagement AöR in Germany. ${ }^{3}$

Recently, Andrea Enria, Chair of the European Banking Authority, has pointed to the dangers and the costs of having more than $€ 1.000$ billion in nonperforming loans in European banks and has called for the creation of a European "bad bank" to manage those loans. In his view, this stock of nonperforming loans is problematic. It is expensive to maintain and, moreover, the equity that banks allocate to these loans might more usefully be employed in new lending. ${ }^{4}$

According to Mr. Enria, this unsatisfactory state of affairs persists because decision making is distorted and markets suffer from severe frictions. Decisions are distorted because banks - and presumably also bank supervisors - have strong incentives to delay the recognition of problems and

\footnotetext{
${ }^{1}$ In addition to FDIC intervention, mention must be made of the Federal Government's conservatorship of the government-sponsored enterprises Fannie Mae and Freddie Mac and the Federal Reserve Bank of New York's acquisition of close to $80 \%$ of the shares of AIG in connection with the provision of initially $\$ 85$ billion, eventually $\$$ 182 billion, in loans from the Federal Reserve Bank of New York and the US Treasury; the shares were held through the AIG Credit Facility Trust, and control rights were exercised by three independent appointed trustees. See FCIC (2011).

${ }^{2}$ For example, the German Kreditwesengesetz (KWG) did allow for bank supervisors to step in and take control even in the absence of default or insolvency, but the priority given to creditor protection was held to imply that the intervention had to follow similar principles as insolvency proceedings. Given the potential systemic repercussions of such an intervention, in October 2008, the German government decided to intervene by providing loan guarantees and/or additional equity on the basis of contracts rather than an imposition by government fiat. See Hellwig (2012).

${ }^{3}$ Atlante is not government-funded, but the Italian government did take the initiative and did lean on Italian banks to provide funding.

${ }^{4}$ See Enria (2017) as well as Haben and Quagliariello (2017).
} 
losses if they do not see any solutions. They may also be distorted by disadvantages to those institutions that move first in addressing the problems. Addressing the problems is hard because legal systems, in particular national insolvency laws, make it difficult, lengthy and costly to address problems in loan performance. Carrying the burden of these loans on the banks' own books may also be a result of information asymmetries causing markets to be illiquid and market prices to be inappropriately low.

Under Mr. Enria's proposal, a European initiative would contribute to improving the availability of data and other information and to improving the legal infrastructure for dealing with nonperforming loans, e.g. for servicing such loans or trading them. A European asset management company would buy such loans "at real economic value", rather than current market price, and then proceed to manage them, winding them down or trading them. Hopefully, the existence and activity of such a company would enhance the liquidity of markets in which such loans could be traded.

Mr. Enria's proposal makes an important contribution to the policy debate. Non-performing loans are indeed a major cause of weakness of banks in Europe. The weakness of banks is probably a major contributing factor for the weakness of economic growth in Europe. As of 2015, GDP in the European Union had hardly risen above the level of 2008. Even in Germany with its supposedly strong economy, GDP growth since 2008 had only been about $7 \%$ in total, $1 \%$ per year on average, about one half of economic growth in this period in the United States.

However, Mr. Enria's initiative raises a number of questions. When taken on its own terms, does his proposal make sense? Is he identifying the right problem and is the solution he proposes apt to deal with that problem? What are the costs of his proposal? Going beyond the proposal, what are the strengths and weaknesses of a strategy of relying on carveouts and bad banks, rather than resolution? The difference between the growth performances of the United States and Europe since 2008 raises the possibility that a reliance on resolution mechanisms might be preferable. If so, why are authorities in Europe so reluctant to rely on the newly created resolution mechanism?

Before entering into a discussion of these questions, I wish to emphasize that I very much agree with Mr. Enria on the need for improved infrastructures for data collection, legal arrangements, and contracting. However, I do not see that the creation of an asset management company will do much to address these issues. For example, I doubt that such an institution would have much of an influence on the development of e.g. Italian insolvency law. Therefore I will not discuss these matters and focus on the potential benefits and costs of setting up an asset management company to deal with nonperforming loans in Europe.

I will discuss the use of clawbacks as a means of avoiding taxpayer involvement in such arrangements. I see clawbacks critically. Clawback provisions are either defeating the purpose of the exercise or not credible, or they subvert the system of bank capital regulation that we have. Thereafter I will discuss the notion of "real economic value" of the assets and its relation to the kind of asset impairment that has been incurred. This notion plays a key role in determining the prices at which assets are transferred. Determination of these prices raises serious issues of governance and avoidance of conflicts of interest. The conflicts of interest are probably smallest in tradable assets with wellestablished procedures for fair-value accounting, mark-to-market or mark-to-model, however imperfect these procedures may be. The conflicts of interest are likely to be very large for assets that by their very nature cannot be traded without large discounts, such as loans. For such assets, holding to maturity - or insolvency of the borrower - may be the best strategy, and an asset management company may have the advantage of being able to afford the time, but that means a different time horizon from the one envisaged by Mr. Enria. In the last part of this paper, I discuss the potential effects of a carveout of assets and their transfer to a government-sponsored asset management company on bank recovery and financial stability. 


\section{CLAWBACKS AND MAKE-BELIEVE}

According to Enria (2017), the proposed arrangement should involve neither state aid nor crosssubsidies between member states. Any losses that the asset management company might make would be covered by clawbacks from the banks. If a bank is unable to cover such losses, its home country would have to make up for the shortfall. I consider this part of the proposal to be highly problematic. To be effective such an arrangement will have to involve a use of taxpayer funds, either outright or in the form of contingent commitments.

The reasoning given and the proposal are very similar to those involved in the German Gesetz zur Fortentwicklung der Finanzmarktstabilisierung (Law for the further promotion of financial market stabilization) of 2009, which also is known as the "bad-bank law". The objective given at the time was to take toxic assets out of banks' balance sheets, so that banks might get on with their business. And costs to taxpayers were to be avoided by clawback provisions. The time horizon envisioned was twenty years rather than the three years that Mr. Enria is talking about, but otherwise the arrangement was the same.

At the time, I criticized the German government's initiative as being a matter of make-believe, with a significant chance that the law would either be ineffective or very expensive for taxpayers. ${ }^{5}$ Subsequent events confirmed this prediction in that no private bank availed itself of the opportunity provided by the law. Even the (public) owners of the Landesbanken preferred to recapitalize these banks on their own rather than use the opportunity provided by the law. The two institutions that did make use of it were Hypo Real Estate (HRE), by that time already fully owned by the Federal Government, and West LB, as part of their negotiation with the European Commission on whether they would be allowed to continue operating. Both cases did not fit the proclaimed intentions of the law - or of Mr. Enria's initiative.

Clawback provisions may be necessary to avoid political controversy, but if they are taken seriously, they defeat the purpose of the exercise. Clawback provisions create a contingent liability of the bank in question. If this liability is put on the bank's balance sheet, one sees that the sale of problem loans from the bank to the asset management company is not actually eliminating the risk from the bank's balance sheet but is merely shifting it from the asset side to the liability side of the balance sheet. Accounting rules may permit the bank to keep this contingent liability off its balance sheet, or to treat it as a kind of equity, but then the operation is a matter of gaming the accounting rules and the regulation rather than addressing the underlying economic problem.

For example, the German law of 2009 stipulated that clawback payments be made out of reported profits, which under German accounting rules would allow banks to keep the contingent liability off their balance sheets. Assuming book-value pricing at the time of the initial transaction, neither the initial transaction nor subsequent value losses on the toxic assets would have any effects on the book value of the banks' equity. ${ }^{6}$ With asset risks taken off the balance sheet, equity requirements would be smaller and banks presumably free to make new loans.

However, such gaming of the accounting rules does not affect the underlying reality. The contingent liabilities that are contained in clawback provisions affect behaviour. From the perspective of shareholders - and of managers remunerated according to "shareholder value" and return on equity

\footnotetext{
5 See Hellwig (2009 b).

${ }^{6}$ If the price assessed for the initial transaction differs from book value, the initial transaction would generate an immediate gain or loss for the bank and hence an immediate effect on bank equity, positive if the price exceeds book value, negative if it falls short. With a solvent bank, under a clawback provision, this windfall loss or gain would be economically irrelevant because whatever loss it might impose the asset management company would eventually have to be repaid through the clawback.
} 
- these contingent liabilities are a component of overhanging debt even if the accountants and the supervisors do not treat them as such.

The situation is similar to the situation with "silent participations" that provide their holders with claims to payments that only come due if the company earns a profit but must be made in advance of any payment to shareholders. There is a tradition in Europe of treating such claims as "equity" because they are junior to all debt and their existence does not induce a risk of default or insolvency. However, from the perspective of shareholders, such claims are debt, namely titles with priority over the shareholders themselves; the very existence of these claims may make it difficult or even impossible to raise equity in the market.

An example is provided by the support that the German government provided to Commerzbank in 2008 and 2009. Of the $€ 18.2$ billion that the government provided, $€ 16.4$ billion took the form of a silent participation, and only $€ 1.8$ billion took the form of a share in the bank's equity ( $25 \%$ plus one share). The existence of the silent participation, with a 9\% coupon in years in which the bank would report a profit under German accounting rules, imposed significant constraints that endangered the bank's recovery: The bank was unable to issue new equity in the relatively good year 2010, and when it did use a combination of measures to issue new equity and repay $€ 14$ billion of the silent participation in the first half of 2011, it was so strapped for equity that it almost succumbed to the turbulences of the second half of $2011 .^{7}$

The suggestion that the sale of nonperforming loans to an asset management company would free bank equity for more appropriate uses presumes that the contingent liability inherent in a clawback rule is not put on the balance sheet or that, if it is put on the balance sheet, it is treated like equity rather than debt. In view of the potential incentive effects on shareholders and managers, I consider either treatment to be problematic.

In assessing the equity of a bank and the potential risks from a lack of equity, it is important to consider not only the bank's ability to absorb losses but also the bank's incentives in making new loans and other investments. ${ }^{8}$ A bank with little equity or, worse, negative equity because losses have been hidden may want to take excessive risks, as happened with savings and loans institutions in the United States in the 1980s; with very high market rates of interest and large mortgage portfolios from the 1960s with relatively low fixed rates that still had decades to go, in the early 1980s, most of these institutions were insolvent but in the absence of fair-value accounting the insolvency was hidden and they were allowed to "gamble for resurrection", taking significant risks that went sour by the late 1980 s, with costs to taxpayers much higher than if the problem had been addressed in the beginning of the decade.

Alternatively, such institutions may become immobile, continuing to lend to their old customers, maintaining the pretence that these customers are solvent long after they have in fact become insolvent because, as long as the insolvency of customers has not been uncovered, the loans need not be written down, and the banks' own books look better. This kind of behaviour contributed significantly to the weakness of productivity growth in Japan since the 1990s: Funds given to de facto insolvent old customers were unavailable for lending to new companies. Even more importantly, the "deep pockets" support provided by banks to their old loan customers prevented new companies from entering the market to compete with these old companies even if, in terms of productivity, they would have been able to do so. ${ }^{9}$ Some of the behaviour of banks that is worrying Mr. Enria today may follow a similar pattern; certainly such behaviour has been prevalent in the context of the worldwide shipping crisis of the past few years, with banks exercising forbearance towards their loan customers, fearful

\footnotetext{
${ }^{7}$ For an account of the difficulties induced by the existence of the $€ 16.4$ billion silent participation, see Expertenrat (2011).

${ }^{8}$ See Admati and Hellwig (2013), Ch. 3.

${ }^{9}$ See Hoshi and Kashyap (2004).
}

PE 587.399 
of triggering credit events and even more fearful of repossessing ships and selling them, possibly at prices that would require revaluations of collaterals on many loans.

In either case, with excessive recklessness or excessive forbearance towards nonperforming loans, the distortions of behaviour depend on the economics of the situation rather than the accounting. To the extent that a bank suffers from a lack of common equity, the economics of the situation are not improved by transforming asset risks into risks from contingent liabilities.

Matters might improve if the transfer of problem assets were to go along with an end to inefficient forbearance. But that may mean that, at the time of the transfer, the problems are laid open, for example, through the size of the haircut that the bank must take on the loan in question. If so, the bank may prefer not to transfer the asset anyway.

The point is that the "bad bank" approach, in contrast to an approach relying on resolution, relies on voluntary contracts, rather than imposition by the authorities. Why would a bank agree to a contract that requires it to lay open the problems it has tried to hide? The German experience with the 2009 law suggests that such agreement will only be forthcoming in very special circumstances. To get a bank to participate voluntarily, it must be offered something. Such an offer may be incompatible with the promise that the project involves no subsidy from taxpayers.

These considerations also apply to the second concern raised by Mr. Enria, the expense of administering a portfolio of nonperforming loans. Such an expense exists for an asset management company as well as the originating bank. Without clawbacks, a bank may be willing to participate, happy to have imposed this cost on the asset management company. With a clawback provision however, the originating bank anticipates that, at the margin, it will end up bearing this cost after all. If the asset management company hires new personnel, without much knowledge of the loan customers in question, the cost may end up being greater than if the bank kept the loans and managed them itself. Anticipation of such an outcome militates against the bank's participating in the scheme.

As for the interference between the management of nonperforming loans and new loans, many banks have recognized this problem and addressed it by creating their own internal "bad banks", i.e. divisions whose sole task it was or is to wind down a portfolio of loans where there was no expectation of further lending in the future. An example is provided by Commerzbank's winding down of Eurohypo or of its shipping loan portfolio. In terms of actual operations, it is not clear that there would be any cost advantage to transferring this task to an outsider. Moreover, with medium size and large banks, the resources involved would be so substantial that bundling of such activities of several banks in one asset management company is unlikely to yield significant scale economies. In the case of Germany's FMS Wertmanagement, for example, the "bad bank" for Hypo Real Estate, with roughly 140 employees, the annual operating cost was initially just below $€ 350$ million and has gone down to just above $€ 200$ million, while the asset portfolio was reduced from ca. $€ 170$ billion to ca. $€ 90$ billion. 


\section{ASSET IMPAIRMENTS AND "REAL ECONOMIC VALUE"}

Proposals to use asset management companies as a means of "freeing" banks from the burdens imposed by impaired assets rely heavily on the notion that "real economic value" of these assets is not sufficiently recognized by markets, and that this discrepancy leaves room for an asset management company to improve the situation. In the following, I discuss this notion.

\subsection{Asset impairments}

First, I take a look at what it actually means for a bank to have "impaired assets". I find it useful to distinguish three kinds of impairment. The first is an outright loss, for example, from the insolvency of a loan customer. The second is an increase in risk, as prospects for the asset in question have become more uncertain. The third concerns a reduction in market value while return prospects from holding the assets to maturity are hardly affected. In a real-world situation, these three kinds of impairment are usually joined but for the purposes of this discussion the distinction will nevertheless be useful.

For example, a worsening of prospects for a loan customer usually affects the mean as well as the variance of the probability distribution of returns from this customer's loans. Under fair-value accounting, the reduction in the mean would in principle call for an acknowledgement of a loss (even though this principle is rarely adhered to). At the same time, the uncertainty about the return may rise. And the market's assessment of the loan may drop, perhaps exaggeratedly so, because with the rise in uncertainty, the market's fears of being taken advantage of may rise. Thus in the subprimemortgage crisis, there was a strong sense that price declines of mortgage-backed securities far exceeded the declines in any reasonable measures of prospective returns from the underlying mortgage loans. ${ }^{10}$

Once an impairment has occurred, there is little that can be done about it. In particular, a loss that has already occurred can hardly be made good again. However, the participants may try to use the lack of transparency in order to avoid taking responsibility or to change the allocation of the loss to their advantage. A simple device would be to delay its acknowledgement in the bank's books and to get someone else to buy the asset at its original value. Most prospective buyers would be afraid of falling victim to such a ploy and shy away from buying, except possibly at a large discount, at which point the originating bank may refrain from selling because a sale at a large discount would require it to take a substantial loss. This consideration provides one explanation for the illiquidity of such markets that Mr. Enria complains about. The question is why a "bad bank" should be able to provide for an improvement - except of course if the "bad bank" is willing to pay a high price for the asset, effectively making a transfer of resources to the bank.

\subsection{What is "real economic value"?}

Enria (2017) avoids the issue by suggesting that the asset should be transferred at a price equal to "real economic value". The notion of "real economic value" has also been central in the European Commission's state aid control of the various measures for transferring assets from banks to government-run or government-guaranteed asset management companies. The problem with this concept is that in a given situation, "real economic value" may be impossible to ascertain with any degree of confidence. Normally, we think of "economic value" as being assessed by markets. But here the presumption is that, because of frictions, market prices do not properly assess "real economic value".

Given the difficulties in assessing "real economic value", there is a good chance that, in any actual transaction between a bank and a public asset management company, "real economic value" will be

10 Hellwig (2009 a), IMF (2009).

PE 587.399 
overestimated. The banks that act as sellers have strong incentives in this direction. A high assessment of "real economic value" reduces the need for a writedown and may even enable them to continue hiding their own insolvency. Moreover, as mentioned above, the need to get the banks to agree to such a sale gives them some leverage in the negotiations about the price.

The determination of "real economic value" ex ante would be superfluous if the authorities followed a "good bank" rather than a "bad bank" approach, along the lines pursued in the Swedish banking crisis of 1992. ${ }^{11}$ Under a good bank approach, the authorities would take over the bank as a whole, sort out the assets, and then sell whatever can be sold, including by privatization of a viable "good bank". The previous owners would retain their shares, and would therefore participate in any excess of the proceeds of the operation over the cost, but they would not get any upfront payment. The payouts that they eventually get would be a measure of "real economic value" ex post (in the Swedish case zero, because the proceeds did not cover the costs of paying off creditors). A recovery and resolution procedure would in principle provide a framework for implementing this approach, but of course the resolution authority would need the resources to actually manage the disposal of the bad assets as well as the sale of the good bank.

In some instances, the authorities themselves may share the bias towards an excessively high assessment of "real economic value" and may prefer the "bad bank" approach for this very reason. A high assessment of "real economic value" may allow them to avoid disagreeable questions about their own past behaviour as supervisors. They may also be pleased if the avoidance of large writedowns keeps a hidden insolvency under cover, enabling them to avoid closing the bank down.

An example is provided by the transfer of assets valued at over $€ 170$ billion from pbb, the renamed Hypo Real Estate, to the government-run asset management company FMS Wertmanagement in the summer of 2010, which took place without any haircuts. By the end of 2011, FMS Wertmanagement had incurred losses of some $€ 12$ billion, mainly from writedowns in anticipation of the haircut on Greek debt that would take place in the spring of 2012. The German government approved the transaction as a way of preparing the subsequent privatization of pbb. The equity of pbb had a book value of less than $€ 2.5$ billion, and the privatization in 2015 brought about $€ 1.2$ billion; without the transfer of assets at face value, the haircut on Greek debt would have bankrupted the bank with no prospect for a privatization. ${ }^{12}$

Other examples of transfers at overvalued prices are given by the experience of Sareb in Spain and more recently hsh portfoliomanagement AöR in Germany. ${ }^{13}$ The more than $€ 2$ billion in additional provisions that Sareb had to take in 2015 and that required a conversion of over $€ 2$ billion of subordinated debt into equity were due to a revision in asset valuations mandated by the Bank of Spain. The $€ 340$ million in additional loan loss provisions that hsh portfoliomanagement AöR had to take per September 30, 2016, reflected asset changes in asset valuations on a portfolio of $€ 2.4$ billion three months after the portfolio had been acquired from HSH Nordbank. In both cases, the

11 For an extensive discussion, see Englund (1999), ASC (2012).

12 As discussed by Cas and Peresa (2016), p. 21, the European Commission had estimated that the transfer price exceeded the real economic value of the portfolio by more than $€ 16$ billion, but had nevertheless approved the transaction on the grounds that the German government was the owner of pbb/Hypo Real Estate as well as FMS Wertmanagement so that the state aid was in fact accruing to the German government itself.

13 The case of WestLB and Erste Abwicklungsanstalt (EAA) may also be mentioned in this context. While EAA works in the institutional framework of the German "bad bank" law of 2009, FMSA, the federal institution in charge of implementing that law, only has a supervisory legal role ("Rechtsaufsicht"). EAA is owned by the former owners of West LB, who had founded it even before the decision to wind West LB down. The original intention had been to transfer assets from West LB to EAA in such a way that the solvency problems of West LB would be reduced and a continuation of the existence of West LB might be more palatable to the European Commission. The European Commission objected that such transfers would be a form of illegal state aid, $€ 3.4$ billion on a total of $€ 77.5$ billion. West LB was closed down after all, and EAA then served the owners as a vehicle to also dispose of assets that had not been transferred initially, e.g. the bank's real-estate/covered-bond subsidiary Westimmo. 
prices at which the assets had originally been transferred had also involved significant haircuts and had been approved by the European Commission, but even so, these prices were too high. In the case of hsh portfoliomanagement AöR the auditors who assessed these prices, as well as the public owners of HSH Nordbank, had persistently seen the global shipping crisis as a temporary event that would in due course be followed by a revival, without any consideration of the impact that an enormous and ever growing capacity overhang would have on pricing in a highly competitive market. ${ }^{14}$ Throughout the years, this analysis had conveniently supported the bank's and the public owners' reluctance to write down shipping loans; the persistence of the shipping crisis and the failure of charter rates to recover had always come as a complete surprise, in the aftermath of the asset sale to hsh portfoliomanagement AöR as well as in previous years. ${ }^{15}$

\subsection{The UBS experience}

Pricing of assets raises problems of governance. In many instances, such pricing is distorted by conflicts of interest. To avoid such distortions, it is important to ensure that solvency considerations do not affect the valuation of assets that are transferred to an asset management company. Arrangements for the Swiss bank UBS provide an example. ${ }^{16}$ In the UBS bailout in 2008, solvency concerns were addressed directly at the level of the government, while an asset management company was created as a special purpose vehicle under the auspices of the Swiss National Bank. To maintain solvency, the Swiss Confederacy provided CHF 6 billion through a mandatory convertible bond, which upon conversion amounted to about $9 \%$ of the bank's equity. At the same time, assets amounting to $\$ 38.7$ billion were transferred to SNB StabFund, a limited partnership that was jointly owned by UBS and the Swiss National Bank. Valuations were provided by external valuation agents, who were not otherwise involved with UBS. The assessed value was about $\$ 1$ billion below the valuation on UBS's books, necessitating an immediate writedown that did not however affect the bank's solvency. Subsequently, SNB StabFund did not have to take any additional writedowns but managed to dispose of the assets so that when the operation was shut down in 2013, the Swiss National Bank had earned \$ 5.2 billion on an investment of just under \$ 35 billion. ${ }^{17}$ Avoiding conflicts of interest in the original asset valuation seems to have been one reason for the positive outcome.

Even so, the favourable outcome for SNB StabFund was by no means a foregone conclusion. The risk for the Swiss National Bank was significant as the funds it provided were on the order of one fifth of its balance sheet and, moreover, involved an exchange rate risk as well as the risk of asset returns in US dollars.

The following factors seem to have played a role. First, about $65 \%$ of the assets involved securities, another $22 \%$ derivatives, and only $13 \%$ loans. Pricing for securities and derivatives would have been more straightforward than for loans because markets and models for such pricing had existed before, even though in the crisis some of them had become dysfunctional; moreover, with fair-value accounting, many of the requisite writedowns had already been taken, and the transfer of assets to

14 For a criticism of the public owners' failure to properly assess the factors underlying the shipping crisis and of their lack of realism concerning the prospective duration of the crisis, see Hellwig (2013), my contribution to the hearing of the Hamburg Bürgerschaft on the proposal to increase the second-loss guarantee for the bank from $€ 7$ billion to $€ 10$ billion. At the hearing, a representative of PricewaterhouseCoopers, the auditor in charge of the valuation in 2016, supported the view that the shipping crisis would be over by the end of 2014.

15 The criticism in Hellwig (2013) relies heavily on and cites from a text that I wrote in 2009 as part of the assessment by the Lenkungsrat Unternehmensfinanzierung of the application of Hapag-Lloyd for public assistance from the Wirtschaftsfonds Deutschland. Already at that time it should have been clear that the shipping crisis was not a temporary phenomenon but would persist until demand had overtaken capacity. For details of the microeconomics see Hellwig (2015).

16 For an account of the UBS experience, see Jordan and Zimmermann (2013).

$1710 \%$ of the funding had come from UBS itself. 
SNB StabFund was not a way to cover up a hidden insolvency. Second, the acquisition took place at a time when markets were in a panic so the recovery that followed provided windfalls on traded assets that could balance losses on repossessed real estate properties.

Third, UBS itself participated as a junior partner in the management of SNB StabFund, with strong incentives to ensure a favourable outcome: UBS had the option to buy back the assets of SNB StabFund after the loan from the Swiss National Bank had been repaid. After this buyback, UBS would get $50 \%$ of any excess of the final value over the amount of $\$ 1$ billion that went to the Swiss National Bank upfront. Thus, when UBS exercised its option and SNB StabFund was wound up on September 30, 2013, the equity of SNB StabFund amounted to $\$ 6.52$ billion, of which Swiss National Bank received $\$ 3.76$ billion and UBS received $\$ 2.76$ billion. ${ }^{18}$ Further incentives for UBS were provided by a warrant that would have allowed the Swiss National Bank to buy 100 million UBS shares at a nominal price of CHF 0.10 per share; exercise of this warrant would have greatly diluted the existing shareholders.

In assessing the UBS experience, it is useful to go back to the above distinction between different modes of impairment of assets. In addition to impairments from actual losses, I referred to impairments from increased uncertainty and impairment from market mistrust of the assets. In the case of UBS, at the height of the post-Lehman panic, there was an extraordinary mistrust of both the bank's assets and the bank's solvency. Because of this mistrust, and because of the overall breakdown of money markets worldwide, market funding for UBS was rapidly eroding. If UBS had responded to this erosion by trying to sell assets, sales prices might have been so low that the very realization of these sales would have caused the bank to become insolvent. UBS was at risk because it had used short-term funding, in particular, money market funding to finance the purchase of long-term assets that turned out to be less liquid than the bank had anticipated.

The experience provides on instance where the notion of a discrepancy between the "real economic value" and the market price of an asset makes sense. If markets are in a state of panic, or, more precisely, if market participants are in a scramble for cash and market prices are determined by how much cash there is and how much is needed, then, for an investor who can afford to hold on to assets, real economic value is higher than the current market price. In this case, being able to wait is a source of economic value. The Swiss authorities' intervention enabled the participants to avail themselves of this value. Equivalently, it prevented the destruction of value through fire sales, which might have contributed to a further implosion of prices and a malfunctioning of the overall economy with further value destruction.

\subsection{Nontradable assets - loans}

Such a situation should not be confused, however, with the absence or illiquidity of markets that are due to information asymmetries. For some of the assets held by banks, in particular, many loans, nontradability lies in the very nature of the assets. A key function of a bank is to perform creditworthiness assessments and to screen out bad risks. Concentration of lending to one borrower in the hands of one or at most a handful of banks saves on the costs of such assessments; the bank or banks involved necessarily have an information advantage. This information asymmetry makes other investors reluctant to buy such assets without large discounts.

In the runup to the financial crisis, banks have tried to make loans tradable by using packaging and tranching techniques to securitize them. The prospect of securitization with guarantees however made for strong incentive distortions in origination. Excessive origination then was a major cause of the crisis.

18 The $\$ 3.76$ billion for equity that went to the Swiss National Bank came on top of some $\$ 1.4$ billion in interest on the loan with which it had funded the operation. 
I am therefore sceptical about the idea of Enria (2017) that creation of a Europe-wide asset management company might provide for the volume that is needed to make asset markets more liquid and permit a rapid sale of impaired assets. Additional volume will not help if the assets are heterogeneous and private information is important. Market illiquidity can be remedied if by their nature the assets in question are tradable in normal times and the illiquidity has been caused by special circumstances. It can hardly be remedied however if by their nature the assets in question are not tradable even in normal times.

These considerations match the experience of the different asset management companies that we have seen since the 2008. At one end of the spectrum, the Swiss StabFund held mainly securities and derivatives and was able to liquidate its holdings fairly quickly. At the other end of the spectrum, asset sales by the Spanish Sareb have been fairly slow, in particular, in areas outside of Madrid and Barcelona; many of the loans it holds are relatively small in value, with residential property as collateral - and accordingly significant heterogeneity in credit risk. ${ }^{19}$ In between, we have the experiences of NAMA in Ireland and FMS Wertmanagement in Germany, which have so far managed to reduce their holdings by $75 \%$ and $50 \%$ respectively. NAMA was able to sell large parts of its portfolio, which was possible because the collaterals were fairly homogeneous, consisting of large commercial real estate development projects. In contrast, FMS Wertmanagement with significant amounts of unimpaired loans and mortgages has not sold many of its assets but has mostly let the contracts run their course; given the funding advantage they have as a government institution, this may actually be more profitable than any attempt to sell the assets.

These different experiences suggest that Enria's (2017) emphasis on tradability and the creation of liquid markets may be misplaced. The important thing is to enable a value maximizing strategy for managing the assets, mainly by providing the time needed to avoid losses from liquidations under pressure. For some assets, in particular loans, such a strategy may require holding to maturity. ${ }^{20}$

Efficiency gains from a carveout and transfer of nonperforming loans to an asset management company might actually come from a greater willingness to let bygones be bygones and to write the loans down, rather than any improvement to their tradability. Debt restructuring with a partial writedown may actually be in the creditors' own interest because the reduction of debt overhang improves the borrower's capacity and willingness to engage in activities that might end up benefiting the creditors themselves. The creditors' ability and willingness to engage in efficient debt restructuring may however be impaired if they suffer from debt overhang themselves and the writedowns pose a threat to their insolvency, more precisely: require them to lay open a hidden insolvency.

In this case, an asset management company might improve on the handling of nonperforming loans by providing for faster writedowns and more efficient restructuring, reducing the debt overhang of the nonfinancial sector. However, the same concerns about insolvency that prevent a bank from dealing efficiently with the problems of debt overhang of its borrowers may also prevent it from agreeing to a transfer of assets to an asset management company unless the asset prices are sufficiently high so that the transfer in fact improves the bank's solvency.

In any case, the time horizon of three years considered by Enria (2017) is unrealistic. Even the Swiss StabFund required five years. For FMS Wertmanagement, I expect that the time horizon may be in the order of twenty years as many of the loans in question have long maturities. Artificially shortening the horizon may be counterproductive. Besides the avoidance of an immediate fire sale in a situation of market mistrust, the time gained to choose a value maximizing strategy is the main source of gains

19 Cas and Peresa (2016).

20 Englund's (1999) of the Swedish banking crisis mentions that losses were perhaps larger than they need have been because the government tried to liquidate or wind up loans very quickly. 
from a government-sponsored asset management company that is not subject to funding pressures in a panicky market. ${ }^{21}$

The long time frames that are required imply that it is yet too early to assess the overall achievements of the asset management companies that were set up after the crisis. As mentioned, the case of UBS was special because the share of tradable assets was exceptionally large. Moreover, the initial assessment of "real economic value" may have been more realistic because governance was stronger. For the other institutions, one may suppose that initial sales efforts focused on those assets where it would be easiest to find buyers and on those where the discrepancy between the prices at which the asset management company had acquired the assets and the prices that could be realized were smallest, perhaps even negative, i.e. allowing the asset management company to earn a windfall profit. Any fast realization of losses would raise questions about distortions in the initial pricing or about the strategy choice and the competence of the asset management company. Losses that may eventually be unavoidable are going to be more palatable to the polity if much time has passed since the asset management company has been set up.

With non-tradable assets such as loans, the problem of determining "real economic value" is particularly vexing. In the Financial Times, John Kay once likened the valuation of a loan to the valuation of a lottery ticket. Should it be valued at cost, at potential return in the event of success, at potential return in the event of failure, and how should the probability of failure be assessed? Quantitative assessments of default probabilities are notoriously unreliable: Loans to different borrowers are heterogeneous, default is a rare event and default probabilities are non-stationary. If the entire economy and the entire banking sector are in trouble, it will be difficult to assess which losses are likely to be transitory and which losses are likely to be permanent.

In this kind of assessment, banks and their owners, as well as the supervisors, are likely to be overoptimistic, as in the example of the shipping loans of HSH Nordbank that I mentioned above. But even if governance problems in the assessment of "real economic value" have been much reduced, the objective difficulties in providing proper value assessments remain. In the case of Spain, as in the UBS example, public assistance to bank solvency came through direct injections of capital, and the divestment of assets to Sareb contributed very little to reducing the gap in the banks' equity. The haircut on these assets amounted to $53 \%$ but even so, as mentioned above, a further haircut was required just two years later. ${ }^{22}$

21 According to the account of the cleanup of the US savings and loans crisis in Curry and Shibut (2000), that operation also took some ten years, and the patience paid off in avoiding losses from fire sales or impatient pressuring of borrowers.

22 FROB (2016). 


\section{ASSET CARVEOUTS, BANK RESTRUCTURING, AND FINANCIAL STABILITY}

To conclude this paper, I consider the contribution that a carveout of assets and transfer to an asset management company can make to the restructuring of banks with impaired assets and the restoration of financial stability. I begin with a brief account of taxpayer involvement. After that I discuss the potential for restructuring at the affected bank, the implications for the financial system as a whole, and the role of the fiscal stance of the government.

\subsection{The need to commit public funds}

It would be an illusion to believe that a government-run carveout of assets and transfer to an asset management company can be done without a commitment of public funds, either upfront or as a contingent liability, or both. One may try to minimize the extent of the commitment through clawback provisions in the contractual arrangements. However, as I argued in Section 2 above, effective clawback provisions defeat the purpose of taking the risks from the impaired assets out of the banks' balance sheets. Without clawback provisions, the risks are effectively transferred but then any shortfall of the asset returns from the acquisition price imposes a loss on the asset management company.

Even with clawback provisions, some risks to public budgets may be unavoidable. Whereas Enria (2017) asserts that his proposal involves no taxpayer money because the risks are eventually borne by shareholders, he neglects the possibility that bank equity may be insufficient to cover the clawback claims. If the clawback provisions are junior to the creditors' claims, as was stipulated in the German law of 2009, and would presumably be stipulated under the Enria proposal, the taxpayers will be hit by losses after all if the bank's equity is insufficient to cover the asset management company's losses. In this case, the taxpayers' contribution benefits the debtholders who would be bailed in if the risks stayed on the bank's books and the bank went into resolution. Alternatively, if the clawback provisions are senior to the claims of debtholders, these debt holders are adversely affected by these provisions. The bank will then find it more difficult to renew maturing debt that is subject to bail-in in resolution. Over time, this might impair the bank's ability to satisfy regulatory requirements for bail-in-able liabilities, MREL or TLAC.

The point is illustrated by the example of hsh portfoliomanagement AöR that I discussed above. In this case, to be sure, there is no clawback provision, so the taxpayers' assumption of the risks attached to the portfolio that was acquired at an assessed value of $€ 2.4$ billion benefits the ca. $10 \%$ outside shareholders of HSH Nordbank. The loss of $€ 340$ million that has already been recorded does not affect their equity position. However, given the poor prospects of the bank, I suspect that the benefit to hybrid and junior debtholders may be even larger. After all, HSH Finanzfonds AöR, the holding company for the shares that are owned by Hamburg and Schleswig-Holstein, has already written down the value of these shares to $€ 1$.

Some countries have tried to limit the commitment of public funds by taking in private investors. To some extent, however, this is merely a make-believe device, motivated in part by Eurostat rules for what counts and what does not count as public debt. Private investors who participate voluntarily do so because they expect a fair return on their investments. Such a return can come from the assets themselves if the private investors have a comparative advantage in managing them. Otherwise it must come from their receiving proper remuneration for their services and for their willingness to take risks. Such remuneration imposes a burden on the government. The burden may not be immediately shown in the accounts but it will nevertheless be there. Such a burden is also there if asset sales are supported by guarantees against losses on those assets.

Participation of private investors may also be obtained through government pressure. However, as shown by the difficulties that Atlante in Italy had in reaching the target for its funding, which already 
was very low, the scope for this method of obtaining private-investor participation without committing government funds is limited. Moreover, if the investors in question are banks and run into difficulties themselves, the government may be in for a bigger problem than it had on its hands initially.

Whether private-investor participation makes a positive contribution to the quality of asset management, depends on circumstances. In the UBS case, the participation of UBS itself enabled SNB StabFund to draw on the prior information that UBS had about the assets in question. One may suppose that this information advantage of the originating institution is also a major reason why banks that have addressed the issue of impaired assets on their own have by and large relied on internal "bad banks" to organize the disposal of the assets.

At this point one might ask whether internal "bad banks" would be an alternative to a governmentsponsored asset management company. I am sceptical about such a suggestion, at least if it comes as a policy initiative with a prospect of government support or government guarantees for the venture. If the bank institutes an internal "bad bank" on its own, without government support, as in the case of Commerzbank, there are no policy and governance issues; ${ }^{23}$ the only question is whether the bank can absorb the writedowns, which in the case of Commerzbank was possible because the bank was earning significant profits in its lending to medium-sized nonfinancial companies. However, if the "bad bank" is imposed from outside and if the potential losses are too large to be absorbed by the bank, as in the case of HSH Nordbank, which instituted an internal "bad bank" as part of its 2011 agreement with the European Commission and obtained a second-loss guarantee for this portfolio from its public owners, all the governance problems attached to legacy assets remain in place. ${ }^{24}$

If the private investors are outsiders, efficiency gains would have to follow the general logic of publicprivate partnerships, i.e. they would be based on the private partner's having special expertise and perhaps a more stringent efficiency orientation than the public partner. The question is to what extent such gains require the sharing of financial responsibility and decision powers. The experiences of the Federal Deposit Insurance Corporation in the United States or of the authorities in Sweden in the 1990s suggest that the requisite skills might also be mobilized by a public institution that draws on private expertise on an ad hoc basis.

To conclude this part of the argument, while there may be advantages to having private partners, including the originating bank itself, participate in the funding and the operation of the asset management company, such participation does not eliminate the need for a commitment of public funds, including the explicit or implicit contingent commitment that goes with the assumption of risks from the assets that are transferred.

Such commitment of public funds benefits incumbent debt holders of the bank and thus runs counter to the principle of the BRRD whereby banks' losses should be borne first by shareholders and then by debt holders in ascending order of the seniority hierarchy. The question is whether the benefits that a carveout and transfer of assets to an asset management company bring relative to a recovery and resolution procedure are worth the costs.

23 Commerzbank had benefited from government support in the form of an equity injection but this support was unrelated to its subsequent use of an internal "bad bank" to wind down its real-estate and shipping loans. The latter was very much influenced by the bank's wanting to give market investors a signal that it was addressing legacy problems forcefully.

24 This internal ,bad bank“ is not to be confused with the hsh portfoliomanagement AöR, which was only created in 2016 and which is directly owned by Hamburg and Schleswig-Holstein. The earlier internal asset carveout left the assets on the books of the bank, but a second-loss guarantee from the public owners reduced the equity needed to support the bank's holding of these assets. Following a first-loss tranche of $€ 3$ billion that was to be borne by the bank, additional losses on the carveout would be borne by the public owners. The amount was initially set at $€ 10$ billion, then lowered to $€ 7$ billion (to reduce the fees that the bank had to pay) and then in 2013 increased again to $€$ 10 billion. 


\subsection{Prospects for recovery}

In assessing the scope for successful bank restructuring through a carveout and transfer of assets to an asset management company, it is important to know why the bank is in trouble and why its assets are impaired. If the bank already has incurred losses that must be considered irredeemable and that threaten its solvency, a successful restructuring requires the solvency problem to be addressed. This can only be done by a recapitalization. The recapitalization may be done explicitly, in which case there is no inherent link to the asset carveout, or it may be done implicitly by a sale of assets at excessively high prices. Thus in the cases of UBS and of the Spanish banks, most of the recapitalization came through direct capital injections, in the case of pbb /HRE, an important part came through the overvaluation of assets transferred to FMS Wertmanagement. In both cases, the restructuring was successful because the recapitalization was large enough to eliminate all concerns about the bank's solvency.

In contrast, the $2009 € 3$ billion recapitalization of HSH Nordbank, together with the additional support through a $€ 10$ billion second-loss guarantee of the bank's public owners did not make for a successful restructuring because it was far from matching the bank's hidden solvency problems. ${ }^{25}$ In this case, one must also doubt that the 2016 carveout and transfer of bad loans to hsh portfoliomanagement AöR will be sufficient for that purpose. Whereas some observers had suggested (and continue to suggest) that nonperforming loans in the bank's portfolio might amount to some $€$ 25 billion, and the bank's management itself had talked about $€ 15$ billion, the transfer only involved $€ 5$ billion in nominal value. Whereas it is difficult to assess the bank's true situation from outside, the discrepancy between these numbers suggests that the public owners may find it difficult if not impossible to privatize the bank by 2018, as stipulated in the 2015 agreement with the European Commission. $^{26}$

Regardless of how the solvency problems are addressed, the use of government funds (or contingent commitments of funds) raises questions about the role of state aid. This is why the European Commission and Eurostat insist that asset prices in the transfers involve proper haircuts. However, given the difficulties of determining "proper economic value", there always is a temptation to claim that the losses are smaller than they might appear and the assessed "real economic value" is larger than it actually is so that the transfer of assets actually provides for a hidden (partial) recapitalization of the bank.

For proper governance and for transparency, it would be desirable to separate the recapitalization from the valuation of the assets that are transferred. However, this may be impossible. The experience of Sareb shows that, even if there is an explicit recapitalization and even if the European Commission's state aid control is involved, it may be impossible to avoid a hidden capital injection through an incorrect assessment of "proper economic value". In cases where the procedure is affected by conflicts of interest, the hidden capital injection is likely to be even larger.

Matters are different if the carveout and transfer of assets only serve to reduce pressures from the funding side of the bank, i.e. to protect the bank from threats to its liquidity and its solvency rather than solvency problems that have already materialized. In this case, the transfer of assets to an extraneous asset management company can be useful by protecting the bank from the need to liquidate assets inefficiently in order to preserve its liquidity. The UBS experience shows that in such a constellation the carveout and transfer of assets can provide benefits that contribute to the restoration

25 As of 2009, the participants were only concerned about the bank's losses from „toxic“ securities in the United States; the effects of the shipping crisis were not yet acknowledged.

26 The 2015 agreement with the European Commission was needed to legitimize the increase of the second-loss guarantee back to $€ 10$ billion, after it had temporarily been lowered to $€ 7$ billion. The agreement allowed for a transfer of assets of $€ 6.2$ billion in nominal value, so some additional transfers may still be possible but far less than what would be needed to free the bank from its nonperforming loans.

PE 587.399 
of the bank's health even though the operation as such does not affect the bank's solvency. In the UBS case, it was important that the solvency problems of UBS had been separately addressed by the equity injection from the Swiss Confederacy. In taking impaired assets out of the bank, SNB StabFund helped to reassure markets that UBS would not be affected by further hits to those assets. The combination of coming in when markets were in a panic, having realistic transfer prices and being able to wait for the improvement in markets then contributed to SNB StabFund's also being financially successful.

The present situation in Europe is different however. Most of the banks that are in trouble do not have the kinds of funding problems that UBS and other institutions had in the fall of 2008. Many of these banks have significant deposit funding, which is less onerous because, with deposit insurance, depositors are less nervous about the banks' asset positions. ${ }^{27}$ Moreover, many weak banks have significant funding from the European Central Bank, which has replaced wholesale money market funding, in some cases even funding from retail deposits. On the funding and liquidity side, a carveout and transfer of assets to an asset management company would only be helpful if the bank in question had run out of collateralizable assets so that it would be unable to obtain further liquidity assistance from the ECB or its national central bank.

The present situation in Europe is also different from 2008 because in 2008, a major cause of bank weakness was the decline of prices for assets in their trading books, a decline that was significantly larger than an assessment of fundamental value would have warranted. Today, the problem is that many untraded assets, such as loans, are in trouble because developments in the real economy have depressed the borrowers' businesses and therefore their ability to pay. In such a situation, there is a strong presumption that many of the loans will not recover. This is particularly true when the borrowers' losses reflect structural change in the economy rather than short-run macroeconomic fluctuations. For example, some of the problems of previously very successful firms in Northern Italy have to do with changes in world trade patterns, more precisely with the fact that these firms are exposed to competition from Chinese firms that have significant cost advantages.

In such a situation, it is quite unlikely that a wait-and-see strategy is going to provide much of an improvement. Any delay risks a repetition of the Japanese experience that was mentioned above, stagnation from a failure to clean up the real economy. The time that might be gained by transferring impaired assets to an asset management company might actually be harmful because the illusion that losses might be prevented or compensated after all stands in the way of new developments.

These considerations are also relevant if the problems of borrowers are due to short-term or mediumterm macroeconomic developments, rather than a structural change that is unlikely to be reversed. To be sure, when the economy turns up again, return prospects of past loans will improve. However, the very existence of debt overhang will affect the behaviour of the borrowers, preventing them from making as much use of the new opportunities as they otherwise would. The problem is evident in the debate about new bank lending to fund new investments. If real investment is low because nonfinancial companies are already heavily indebted, then loan-financed new investments are unlikely to be forthcoming and, if they are, they may just increase the problem of debt overhang.

As mentioned in Section 3.4 above, some writedowns may be in the interests of all parties. Moreover, an asset management company that is itself unencumbered by debt overhang might improve the prospect of achieving such debt forgiveness efficiently. However, this is only possible if the banks' solvency problems can be addressed in some other way.

27 In contrast, in Spain in 2012, banks lost significant amounts of deposit funding. Depositors saw significant redenomination risk as well as significant risk of the government's being unable or unwilling to address the problems. The Spanish government's use of substantial ESM funding to inject capital into banks, and the ECB's contributing to the dispelling of redenomination risk addressed these concerns. As in the UBS case, the very visible actions taken to restore bank solvency by capital injections played a key role. 
In the context of nonperforming loans, in contrast to the case of market freezes for certain assets (the UBS experience), I am sceptical about the prospects for bank recovery unless the solvency problems of banks are addressed. Once the losses are there, one needs to face them and to acknowledge that someone must bear them.

Under the BRRD, as under traditional insolvency law, "someone" means shareholders and, after the equity is exhausted, creditors in ascending order of the seniority hierarchy. Carving out assets and transferring them to an asset management company protects creditors but then the taxpayer must take over the burden or the prospects for recovery are poor. An excessively high assessment of the "real economic value" of the assets may appear as a way to get around the bail-in principle of the BRRD. However, if the amounts are insufficient, a recovery is not to be expected.

\subsection{The conflict between the preservation of banks and bank profitability}

Authorities seem reluctant to avail themselves of the resolution tool even though we now have the requisite legal infrastructure. Recovery and resolution procedures are seen as disruptive. Having the authorities take control disrupts standard decision making and operations in banks. Bailing in debt holders hurts politically favoured constituencies and may pose a risk of domino effects between financial institutions.

Exercising forbearance, towards the banks and towards the loan customers may seem like a way to avoid rocking the boat, while the cost in terms of slow growth and stagnation is initially not visible. Moreover, didn't we learn from Bernanke (1983) that we need banks to stay in operation so that we do not lose their expertise in assessing loan customers? And doesn't this mean that we should beware of a resolution procedure that puts the bank's very existence at stake, whereas a carveout and transfer of assets would leave the bank in existence, free to do something new?

Continuity however has disadvantages as well as advantages. If the problems are due to structural change, continuity is harmful, a way to continue the same things as before when change is needed. Trying to maintain existing institutions is also problematic if there is excess capacity in banking and banks are unable to earn proper margins. Loan customers may like the low interest rates that result from a highly competitive banking sector, but then there is a good chance that the problems caused by these low rates will eventually become a burden for the taxpayer.

In the twenty years before the Lehman bankruptcy, banks and banking in the European Union have grown substantially, and there were significant increases in the intensity of competition in financial markets. ${ }^{28}$ The intensity of competition induced banks to take more risks, in some cases unconscionable risks, which contributed to their vulnerability in the crisis. For example, the reliance of Dexia and Hypo Real Estate on wholesale funding through money markets was to some extent a result of competition in the real-estate/covered-bond sector being so intense that banks had to rely on short-term funding for the excess coverage i.e. for the amount by which the collateral exceeded the value of their covered bonds. Whereas some banks could use customer deposits, Dexia and Hypo Real Estate did not have much of a deposit base and had to use short-term money market borrowing. When money markets froze in September 2008, they had serious liquidity problems.

As mentioned in the introduction, the European response to the crisis has been to try and avoid bank bankruptcies. One consequence of that strategy has been a lack of exit and a preservation of excess capacity that depresses the profitability of banks and, incidentally makes it even more difficult for the banks to deal with past losses.

In this context, it is useful to go back again to the case of pbb /Hypo Real Estate and FMS Wertmanagement. As mentioned above, the transfer involved a significant amount of state aid, which

28 See ASC (2014), Expertenrat (2011).

PE 587.399 
saved pbb from becoming insolvent from the Greek debt haircut and prepared the subsequent reprivatization of the bank. The European Commission had actually estimated the amount of state aid to amount to over $€ 16$ billion but had nevertheless approved the transaction on the grounds that by this time, the German government was the owner of pbb /Hypo Real Estate as well as FMS Wertmanagement so that the state aid involved was in fact accruing to the German government itself. ${ }^{29}$ This argument overlooks the effects of the preservation of pbb on the other market participants.

I suspect that the German government's determination to maintain this bank as a player in publicsector and real-estate finance contributed significantly to the difficulties that Commerzbank had in finding a buyer for Eurohypo, an immediate competitor, as demanded by the European Commission in connection with the public support for Commerzbank in the crisis. Eurohypo was eventually wound down, so indirectly the public subsidy to pbb /Hypo Real Estate led to the market exit of another important institution. ${ }^{30}$ While it seems clear that there had been excess capacity in the market and that some exit must occur, it is highly problematic for the decision as to which institution must exit to be driven by the state aid involved in an excessive price for assets transferred to a government-run and government-guaranteed "bad bank".

In principle, these concerns might be addressed by the European Commission's state aid control. However, if state aid control is exerted bank by bank, the results may be somewhat haphazard. In the case of the German covered-bond sector, the permission of state aid for pbb/Hypo Real Estate and privatization mandates for Eurohypo (Commerzbank) and Westimmo (West LB) induced the preservation of one and the exit of the other two. The result is still preferable to a situation where all three would have stayed in the market but I wonder whether anyone has ever considered the system as a whole. ${ }^{31}$

Some of the measures imposed by the European Commission may also have imposed additional risks on the banks. For example, the requirement that HSH Nordbank reduce its share in the market for shipping loans prevented the bank from participating in the financing of new and ever larger container ships, i.e. the very ships that have lower average variable costs than the old ships the bank had financed before and that may prevent these old ships from ever earning margins again that might be used for debt service.

In Spain, where the entire banking system was involved, the European Commission and the Bank of Spain seem to have used a more systemic approach, encouraging mergers so as to reduce the total number of banks and imposing large reductions in branch networks, staff and balance sheets. ${ }^{32}$ Spanish banks are still suffering from low profitability, but this may at least partly be due to the ECB's monetary policy having depressed long-term interest rates and thereby the margins that can be earned by maturity transformation. It is to be hoped that once market rates of interest return to a more normal constellation, the structural adjustment imposed by the European Commission and the Bank of Spain might enable the banks to become profitable again without engaging in overly risky activities.

29 See Cas and Peresa (2016), p. 21. Their discussion of FMS Wertmanagement does not dwell on the fact that this asset management company was only created in 2010, almost two years after the initial support to Hypo Real Estate 2008 and one year after the government's acquisition of remaining shares in the bank.

30 The fate of Westimmo, another direct competitor, may also be mentioned in this context. The parent West LB was also unable to sell West LB and put it into Erste Abwicklungsanstalt, the other "bad bank" under the auspices of the 2009 law. Following a significant downsizing, with an exit from the acquisition of new customers, eventually Westimmo could be sold to Aareal Bank in 2015.

31 On this point, see also Expertenrat (2011). That report actually suggested that the German government should consider to put all of pbb/Hypo Real Estate into FMS Wertmanagement and then wind the bank down. The assessment of the consulting firm Booz, Allen, Hamilton on which the government had based its decision to maintain and reprivatize pbb had considered the fees that the bank was paying to the government for administration of FMS Wertmanagement as a cost without realizing that the government itself was the recipient of these fees.

32 For details, see FROB (2016). 


\subsection{Dangers to financial stability}

The persistence of excess capacity in the financial system poses a serious threat to financial stability. One aspect of this threat is the incentive to "gamble for survival", i.e. to take excessive risks as the only means of earning profits.

Another aspect of the threat concerns the reduced ability of banks to commingle losses from some operations and profits from others, across business lines and across periods. Before the 1990s, competition in banking and finance in Europe was less intense, and many banks used the smoothing of reported earnings (and dividend distributions) as a way to hide and absorb losses in bad years as well as some of their profits in good years. The intensification of competition has reduced their profit margins and their ability to smooth over losses by this mechanism. At the same time, the erosion of profitability has reduced their ability to go to the market and raise new equity at prices that did not hurt incumbent shareholders too much. ${ }^{33}$ As a result, the implications of ongoing losses for bank solvency and for financial stability are significantly more serious today than in the decades before 1990. A policy of preserving banks in the name of avoiding disruptions in the financial system exacerbates these problems and thereby poses a risk to financial stability.

Finally there are concerns about the fiscal stance of governments. These take two forms. First, the protection of creditors that is involved in setting up a bad bank with an outright or a contingent commitment of public funds may strain the fiscal capacity of the state. In 2012, market fears of the amount of public funds that would be required to restore the solvency of Spanish banks contributed to pessimistic assessments of Spanish government debt and to the notion that Spain might have to leave the monetary union, which in turn motivated a large outflow of funds from Spanish banks. The threatening crisis was averted when (i) Spain recognized the problem and got European support for dealing with it and (ii) the ECB made clear that it would act to stabilize the system. This outcome however should not make us overlook the very real danger that, when an entire banking system is in crisis, the funds needed to clean up the problems and to allow the system to recover may overtax the government's capacity, at least in an institutional context where the government has no say over the interventions of the central bank.

Proponents of carveouts and transfers of assets to asset management companies would probably argue that their proposals are precisely designed to limit the fiscal burden of the banks' problems. Apart from special cases like that of UBS, I do not share this assessment. By taking assets and risks out of the banks and doing so at prices that the banks accept, the authorities shift some of the burden of the banks' problems from the banks' creditors to the taxpayer. Having private investors share in the exercise does not help if the private investors insist on contractual arrangements that allow them to earn attractive returns for their engagement. The fiscal implications may be hidden by the accounting but they will still be there.

Second, fear of the implications for the government's fiscal stance may cause the authorities to proceed to a less than complete cleanup of bank balance sheets. The slowness of the recoveries of banks in Ireland and Spain probably reflects the fact that even after the authorities had intervened, in 2010 and 2012, the banks continued to hold impaired assets in their books. In a situation where the viability of the government's fiscal stance is at stake, there are likely to be strong incentives to shape the intervention in such a way that risks to this viability are limited. One way to do so is to leave assets with the banks even though they are impaired. Another way to do so is to take in private investors, possibly under contracts that may in the long run increase the burden to taxpayers. ${ }^{34}$

33 See Admati et al. (2013) on the effects of debt overhang on incentives to raise new equity.

34 See Gandrud and Hallerberg (2014) for an extensive discussion of the impact of Eurostat rules for accounting for public debt on the extent to which private investors were made to participate in ,bad banks“. 
These remarks are not meant to deny the stability concerns attached to the bail-in of creditors under a resolution procedure. I have on past occasions criticized that the BRRD's complete silence on fiscal backstops is problematic, especially in view of the many exemptions from bail-in that the BRRD stipulates. ${ }^{35}$ However, the wholesale avoidance of bail-in of creditors that occurs when a governmentguaranteed asset management company takes over impaired assets is also problematic and also poses a risk to financial stability. 


\section{CONCLUSIONS}

The large stock of nonperforming loans in European banks exerts a negative influence on bank lending and economic growth. The question is what can be done about it. Ordinarily, dealing with nonperforming loans would be in the competence of the banks; they might initiate insolvency proceedings, or they might voluntarily agree to debt restructurings and write-downs. Such choices of banks are however distorted if the banks themselves must fear for their solvency. Given the threats to bank solvency, a recovery and resolution procedure might seem appropriate. Whereas in 2008/09, such procedures were not followed because the legal infrastructure was not there, by now, with the BRRD and the SRM, the infrastructure is there, but banks and their governments still refrain from using it.

As an alternative, Enria (2017) has proposed the creation of a Europe-wide asset management company, a "bad bank" that would acquire impaired assets from banks and manage them to achieve maximal returns, hopefully by selling them to investors in markets that cease to be illiquid once there is sufficient volume. According to the proposal, a clawback requirement would ensure that such an arrangement need not involve any use of taxpayer funds.

The preceding analysis suggests that clawback requirements are problematic. If they are credible they are likely to defeat the purpose of the exercise because risk is merely shifted from the asset side to the liabilities side of the banks' balance sheet. The accounting rules may allow the banks to hide this risk but then the accounting rules do not do justice to the economics of the situation. If, as seems likely, the clawback provisions are junior to the debt holders' claims, then even with clawback provisions, the arrangement involves a bailout of creditors.

Proposals for the use of "bad banks" to remedy problems in banks rely on the notion that "real economic value" is not properly reflected in asset prices and that a transfer of assets at prices reflecting "real economic value" could be made without an implicit subsidy. For tradable assets, with panicky markets, e.g. because of cash-in-the market pricing, this view may be appropriate. The experience of the Swiss National Bank with UBS provides an example. Loans, however, are by their very nature not easily tradable without significant discounts. Here, the notion of "real economic value" requires an assessment of future debt service, which in turn hinges on an understanding of the underlying sources of the borrower's problems. In this exercise there is plenty of room for manipulating the assessment so that the price at which the asset is transferred involves a subsidy to the selling bank. If it does not involve a subsidy, the bank may be unwilling to sell the asset in the first place because the sale would require it to lay open the losses it has incurred, possibly uncovering a hidden insolvency.

Success of the operation in providing for a recovery of the bank depends on the extent to which threats to the bank's solvency are eliminated. In a constellation like that of UBS, such elimination may be obtained simply because the asset management company is able to hold on the assets without worrying about its own funding and therefore can afford to wait until market shave become less panicky. With nonperforming loans, which do not have active markets even in good times (except with large discounts), the elimination of threats to the bank's solvency is likely to depend on the extent to which public funds are committed, explicitly through a recapitalization or implicitly through an excessive transfer price, outright through a payment for a capitalization or an asset purchase or on a contingent basis through guarantees for loans that fund the asset management company.

If sufficient funds are provided, the operation is likely to be successful in providing for a recovery of the bank. However it also entails risks to the financial stability. Relying on carveouts and asset management companies rather than a recovery and resolution procedure under the BRRD maintains the continuity of existing institutions. This may seem advantageous as a way of not rocking the boat. At the same time, however, the preservation of available capacities makes for an artificial barrier to 
market exit. Market exit may however be required if there are excess capacities and competition is so intense that banks cannot earn profits unless they take undue risks.

The shift of the burden of problems from impaired assets from creditors to taxpayers may also threaten the fiscal capacity of the state. Such threats may induce market reactions that are themselves a threat to financial stability. Alternatively, the fears of such threats may induce governments to limit the extent of the clean-up, which in itself contributes to having the problems of overhanging stocks of impaired assets persist. 


\section{REFERENCES}

- Admati, A.R., and M.F. Hellwig (2013), The Bankers' New Clothes, Princeton University Press, Princeton, N.J.

- Admati, A.R., P.M. DeMarzo, M.F. Hellwig, and P.C. Pfleiderer (2013), The Leverage Ratchet Effect, Max Planck Institute for Research on Collective Goods, Preprint 2013/13 (revised 2015), forthcoming, Journal of Finance, http://papers.ssrn.com/sol3/papers.cfm?abstract id=2304969.

- ASC (2012), Forbearance, resolution, and deposit insurance, Report 01/2012 of the Advisory Scientific Committee of the European Systemic Risk Board, https://www.esrb.europa.eu/pub/pdf/asc/Reports_ASC_1_1207.pdf?c4a55781325f99ef619100f7 $\underline{\mathrm{d} 239321 \mathrm{a}}$

- ASC (2014), Is Europe Over-Banked, Report 04/2014 of the Advisory Scientific Committee of the European Systemic Risk Board, https://www.esrb.europa.eu/pub/pdf/asc/Reports_ASC_4_1406.pdf?5fb1382c5a560f243ecf1989 $\underline{\operatorname{cfd} 37 f 4 c}$

- Bernanke, B. S. (1983), Nonmonetary Effects of the Financial Crisis in Propagation of the Great Depression, American Economic Review 73 (3), 257 - 276.

- Cas, S.M., and I. Peresa (2016), What makes for a Good 'Bad Bank'? The Irish, Spanish and German Experience, Discussion Paper 036/September 2016, Directorate General for Economic and Financial Affairs, European Commission, http://ec.europa.eu/info/publications/what-makesgood-bad-bank-irish-spanish-and-german-experience_en

- Curry, T., and L. Shibut (2000), The Costs of the Savings and Loan Crisis: Truth and Consequences, FDIC Banking Review 13, 26 - 35.

- Englund, P. (1999), The Swedish Banking Crisis: Roots and Consequences, Oxford Review of Economic Policy 15, 80 - 97.

- Enria, A, (2017), The EU banking sector -risks and recovery: A single market perspective, Presentation at the ESM Seminar, Luxembourg, January 30, 2017 https://www.esm.europa.eu/sites/default/files/2017_01_30__esm_risk_and_adjustment_at_eu_banks.pdf

- Expertenrat (2011), Strategien für den Ausstieg des Bundes aus krisenbedingten Beteiligungen an Banken: Gutachten des von der Bundesregierung eingesetzten Expertenrats (Strategies for the Federal Government's exit from crisis-induced participations in banks: Report of the committee of experts appointed by the Government of the Federal Republic of Germany), http://www.bundesfinanzministerium.de/Content/DE/Standardartikel/Themen/Internationales_Fi nanzmarkt/Finanzmarktpolitik/2011-02-15-gutachten-bankenbeteiligunganlage.pdf;jsessionid=C7B924016CA2D8DB29D82B0C57E67590? _blob=publicationFile \&v= $\underline{3}$

- FCIC (Financial Crisis Inquiry Commission) (2011), The Financial Crisis Inquiry Report, Washington, D.C.

- FROB (2017), The restructuring of the Spanish banking sector 2009 - 2016, https://ec.europa.eu/portugal/sites/portugal/files/rdr17_carlos_san_basilio_15april2016_en.pdf 
- Gandrud, C., and M. Hallerberg (2014), Bad Banks in the EU: The Impact of Eurostat Rules, Bruegel Working Paper 2014/15, Bruegel, Brussels.

- Haben, P., and M. Quagliariello (2017), Why the EU needs an asset management company, Central Banking, February 2017, http://www.centralbanking.com/central-bankingjournal/opinion/2481794/why-the-eu-needs-an-asset-management-company

- Hellwig, M.F, (2009 a), Systemic Risk in the Financial Sector: An Analysis of the Subprime Mortgage Financial Crisis, De Economist 157, 129 . 207.

- Hellwig, M.F. (2009 b), Schriftliche Stellungnahme für die Öffentliche Anhörung des Haushaltsausschusses des Deutschen Bundestages zum Gesetzentwurf der Fraktionen der $\mathrm{CDU} / \mathrm{CSU}$ und SPD, „Entwurf eines Gesetzes zur Fortentwicklung der Finanzmarktstabilisierung" am 15. Juni 2009, (Written statement for the public hearing on June 15, 2009 of the Budget Committee of the Bundestag concerning the draft bill of the parliamentary parties of the CDU/CSU and the SPD "Draft bill for the further promotion of financial market stabilization", June 15, 2009).

- Hellwig, M.F. (2012), The Problem of Bank Resolution Remains Unsolved: A Critique of the German Bank Restructuring Law, in: P.S. Kenadjian (ed.), Too Big To Fail - Brauchen wir ein Sonderinsolvenzrecht für Banken?, De Gruyter Verlag, Berlin and Boston 2012, 35 - 63.

- Hellwig, M.F. (2013), Stellungnahme zur Anhörung des Haushaltsausschusses der Bürgerschaft der Freien und Hansestadt Hamburg über die Wiedererhöhung der Ländergarantie für HSH Nordbank am 30. April 2013, (Written statement for the public hearing on April 30, 2013 of the Budget Committee of the Bürgerschaft of the City of Hamburg concerning the increase of the guarantees of the Länder Hamburg and Schleswig-Holstein for HSH Nordbank).

- Hellwig, M.F. (2014), Yes, Virginia, There is a European Banking Union! But it May Not Make Your Wishes Come True, Max Planck Institute for Research on Collective Goods, Bonn, Preprint 12/2014, http://papers.ssrn.com/sol3/papers.cfm?abstract_id=2487757

- Hellwig, M.F. (2015), Neoliberales Sektierertum oder Wissenschaft? Zum Verhältnis von Grundlagenforschung und Politikberatung in der Ökonomie, Max Planck Institute for Research on Collective Goods, Bonn, https://papers.ssrn.com/sol3/papers.cfm?abstract_id=2688898

Preprint

$17 / 2015$,

- Hoshi, T.M., and A. Kashyap (2004), Japan's Financial Crisis and Economic Stagnation, Journal of Economic Perspectives 18 (Winter), 3 - 26.

- IMF (International Monetary Fund) (2008), Financial Stress and Deleveraging: Macrofinancial Implications and Policy, Global Financial Stability Report, October 2008, Washington, D.C., Ch. 3.

- Jordan, T., and M. Zimmerman (2013), Winding up the SNB StabFund transaction, Presentation $\begin{array}{lllll}\text { at News } & \text { Conference } & \text { November } & \text { 8, }\end{array}$ http://www.snb.ch/en/mmr/reference/pre_20131108/source/pre_20131108.en.pdf . 
Европейски парламент Parlamento Europeo Evropský parlament Europa-Parlamentet Europäisches Parlament

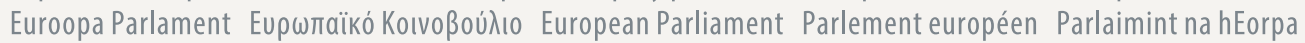
Europski parlament Parlamento europeo Eiropas Parlaments Europos Parlamentas Európai Parlament

Parlament Ewropew Europees Parlement Parlament Europejski Parlamento Europeu Parlamentul European Európsky parlament Evropski parlament Euroopan parlamentti Europaparlamentet

IPOL DIRECTORATE-GENERAL FOR INTERNAL POLICIES

EGOV ECONOMIC GOVERNANCE SUPPORT UNIT

Contact:egov@ep.europa.eu

For more information: http://www.europarl.europa.eu/committees/en/ECON/home.html

PE 587.399

ISBN 978-92-846-0611-5 (paper)

ISBN 978-92-846-0610-8 (pdf) 